\title{
Percepção acadêmica da extensão em ginástica laboral e sua contribuição para a formação profissional
}

\author{
Alessandra Fontana \\ Alessandra Salerno \\ Carlla Henchen \\ Helena Bordignon \\ Josiane Schadeck de Almeida Altemar \\ Carina Fátima Brum
}

CADERNO DE RESUMOS

Fisisenectus. Unochapecó Ano 1 - Edição especial - 2013 p. 136

Alessandra Fontana, acadêmica do $6^{\circ}$ período de Fisioterapia da Universidade Comunitária da Região de Chapecó (Unochapecó), alessandra.f@unochapeco.edu.br

\section{Resumo}

Introdução: Instituições de ensino superior denominadas de universidade comunitária precisam constituirse de ensino, pesquisa e extensão vinculada à comunidade. Neste contexto, é por meio da extensão universitária que o acadêmico tem a oportunidade de vivenciar o panorama teórico-prático, seguindo a reorientação da formação profissional. O projeto de ginástica laboral (GL) da Unochapecó iniciou em 2003 com foco nos estudantes (por meio da vivência prática com o futuro campo profissional), mas que tinha como finalidade também oferecer uma atividade para melhora da qualidade de vida, tendo como beneficiário os funcionários. Objetivos: Apresentar a percepção acadêmica das bolsistas do projeto de extensão ginástica laboral e as contribuições que este apresenta para o processo de reorientação na formação profissional em saúde no âmbito multiprofissional. Metodologia: Participam do projeto estudantes dos cursos de Educação Física e Fisioterapia, fazendo a articulação e integração multiprofissional e interdisciplinar. As atividades acontecem nos períodos matutinos, vespertinos e noturnos, compreendendo dez horas semanais para cada bolsista; as aulas têm duração de 12 minutos para cada setor escolhido previamente. Os planejamentos das atividades foram preestabelecidas através de um cronograma de atividades mensal, elaborado pela coordenação do projeto. Este prioriza exercícios de alongamento, fortalecimento muscular, massagem e recreação. Na elaboração das aulas, são retomados conhecimentos teóricos, vistos dentro dos componentes curriculares da graduação, para que posteriormente aconteça a supervisão do planejamento, os quais são orientados pelos professores de Educação Física e Fisioterapia conjuntamente. Resultados: Nas aulas de ginástica laboral, percebe-se que, apesar do planejamento realizado previamente, cada abordagem acontece de forma diferente, devido ao perfil de cada setor, número de funcionários e materiais disponíveis. O envolvimento do grupo como um todo eleva o nível do projeto, pois a articulação das áreas do conhecimento intensifica a abordagem interdisciplinar. Além disso, o projeto propicia aos bolsistas uma vivência prática, sendo este o primeiro contato real com um campo de atuação profissional. Considerações finais: Considera-se que o projeto de extensão em ginástica laboral da Unochapecó contribuiu no aprimoramento de conhecimento a partir das necessidades encontradas diante da prática deste. Hoje se sabe a importância da consciência corporal, relacionamento interpessoal, trabalho multiprofissional e interdisciplinar, oralidade e da responsabilidade sobre a execução das aulas. Assim, os estudantes se sentem confiantes diante aos desafios que poderão surgir no campo profissional e mais aptos para interagir e relacionar com pessoas em diversos espaços.

\section{Palavras-chave}

Percepção. Extensão comunitária. Comunicação Interdisciplinar.

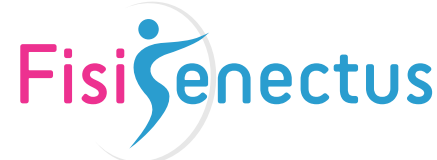

